[44] Philipp, H. R., and E. A. TAF': J. Physics Chem. Solids 1, 159 (1956); 3, 1 (1957). - - Physic. Rev. 106, 671 (1957).

[45] Philutrs, J. C.: Physic. Rev. 136, A 1705, A 1721 (1964).

[46] Prok, H.: In Landolt-BöRnstein: Zahlenwerte und Funktionen (Hrsg. K. H. HellWEGE), S. 869, I. Band, 4. Teil, 6. Aufl. Berlin, Göttingen, Heidelberg: Springer 1955.

[47] Platzman, R., u. J. Franck: Z. Physik 138, 411 (1954).

[48] Porter, G. B., u. H. L. SchläFre: Ber. Bunsenges. f. phys. Chem. (früher Z. Elektrochem.) 68, 316 (1964).

[49] Rabtnowitch, E.: Revs. mod. Physics 14, 112 (1942).

[50] Scheire, G.: Z. phys. Chem. (B) 5, 355 (1929);

- Naturwissenschaften 17, 86 (1929).

[51] SсHокNeCht, G.: Z. Naturforsch. 12a, 983 (1957).

[52] SeItz, F.: [a] The Modern. Theory of Solids. New York, London: McGraw-Hill Book Company, Inc., 1940;

- $[b]$ J. chem. Physics 6, 150 (1938).

[53] Slater, J. C.: J. Physics Chem. Solids 8, 21 (1959).

[54] WANNIER, G. H.: Physic Rev. 52, 191 (1937).

(Eingegangen am 19. November 1965)

\title{
Annotationes et Errata
}

\section{Porphyrins. IV. Extended Hïckel Caleulations on Transition Metal Complexes}

Theoret. chim. Acta (Berl.) 4, 44 (1966)

$$
\text { By }
$$

M. Zerver and M. Gouterman

Eq. (4), page 46, should read

$$
H_{p q}=\left\langle\chi_{p}\left|H_{e f f}\right| \chi_{q}\right\rangle=\frac{1}{2}\left(H_{p p}+H_{q q}\right) S_{p q}\left[\varkappa+(1-\chi) \delta_{p q}\right] .
$$

\section{Valency Structures for $\mathbf{N}_{2} \mathbf{O}_{4}$}

Theoret. chim. Acta (Berl.) 2, 437-452 (1964)

$$
\text { By }
$$

\section{R. D. Harcourt}

p. 444 Line 17 down: Read VII for II.

p. 445 Table 1: Headings shold be $i$, ii, iii and iv.

p. 447 Line 2 up: Read an orthogonal for orthogonal an.

p. 449 Line 15 down: Read $\Phi$ for $\Psi$

p. 451 Line 10 down: $\operatorname{Read}\left(\frac{s_{2}+s_{4}}{\sqrt{2}}\right)^{2}$ for $\left(\frac{s_{2}+s_{4}}{2}\right)^{2}$

Valeney Struetures for Oxalate and Dithionite Anions and Dimers of Nitrosoalkanes

Theoret. chim. Acta (Berl.) 3. 194-201 (1965)

By

\section{R. D. Harcourt}

p. 195 Table 1: first row: 0.32 for 0.32 .

p. 196 Table 2: The $\mathrm{C}_{2} \mathrm{O}_{4}^{2-}$ weights have been incorrectly reported - they obtain for $\mu=0.5$ instead of 0.6 . For $\mu=0.6$, the weights reported as $0.32,0.16$ and 0.02 should read $0.28,0.19$ and 0.03 . The weights $0.24,-0.06$ and 0.32 become $0.19,-0.07$ and 0.38 . These alterations do not affect he conclusions of the paper.

p. 199 Line 23 down: Read

for

$$
\begin{gathered}
\left|\varphi_{1}^{\alpha}\left(\frac{\varphi_{4}+\varphi_{3}}{\sqrt{2}}\right)^{\beta} \varphi_{3}^{\alpha} \varphi_{2}^{\beta}\left(\frac{\varphi_{1}+\varphi_{2}}{\sqrt{2}}\right)^{\alpha} \varphi_{1}^{\beta}\right| \\
\left|\varphi_{4}^{\alpha}\left(\frac{\varphi_{4}+\varphi_{3}}{\sqrt{2}}\right)^{\beta} \varphi_{3}^{\alpha} \varphi_{3}^{\beta}\left(\frac{1}{\sqrt{2}}\right)^{\alpha} \varphi_{1}^{\beta}\right|
\end{gathered}
$$

p. 200 Line 2 of footnote: Read $\sigma_{4}-$ for $\sigma_{2}-$. 